\title{
Cum on Feel the Noize
}

\section{JUSTIN CLEMENS}

UNIVERSITY OF MELBOURNE

\author{
Greg Hainge \\ Noise Matters: Towards an Ontology of Noise \\ Bloomsbury, New York, 2013 \\ ISBN $978441160461(\mathrm{hb}) 9781441111487$ (pb) \\ RRP \$110 (hb) \$36.99 (pb)
}

In late February 1973, Jim Lea and Noddy Holder's anthem Cum on Feel the Noize entered the UK pop music charts at number one. Across various accounts of the song's genesis the recurring theme is that it was an attempt to introduce into their recording the sound of the crowd responding to Slade's sound in live performances. Put another way, the original sound emitter becomes a receiver in order to re-emit the emissions of the receiver back to their source. Although this kind of targeting, expropriation and reintegration of audience response has recently been corporatised as 'crowd-sourcing', that shouldn't dull us to its appeal. The scrambling transformation of inputs and outputs also involves a self-conscious scrambling of the sensorium-you no longer simply hear but rather feel the noise. The noise-affect ISSN 1837-8692

Cultural Studies Review 2014. ( 2014 Justin Clemens. This is an Open Access article distributed under the terms of the Creative Commons Attribution 4.0 Unported (CC BY 4.0) License

(https://creativecommons.org/licenses/by/4.0/), allowing third parties to copy and redistribute the material in any medium or format and to remix, transform, and build upon the material for any purpose, even commercially, provided the original work is properly cited and states its license.

Citation: Cultural Studies Review (CSR) 2014, 20, 4088, http://dx.doi.org/10.5130/csr.v20i2.4088 
couplet overrides the sound-sense couplet in a targeted barrage of syncopated feedback. At the same time, the affirmation of felt noise is also its recuperation for music and monetisation. Noizes ain't always noizes, it seems, or, they iz and they izn't at once.

The paradox of noise is at the centre of Greg Hainge's new book. As its title asserts, Hainge seeks to extract an ontology from the manifold material apparitions of noise. In other words, Hainge is proposing a cultural treatise on the being of noise and also on the noise of being-on being as noise. To do so, he draws on what is almost a disciplinary sub-field of noise studies whose key informants include Leon Cohen, Paul Hegarty, Douglas Kahn, Bart Kosko, Hillel Schwartz, Jonathan Sterne, and the tutelary French geniuses Jacques Attali, Michel Serres and Gilles Deleuze. ${ }^{1}$ Noise studies shouldn't be confused with its close relation, sound studies. As Hainge (and others) emphasise, historically sound is one of the ways in which noise has been domesticated. Accordingly, noise ought not to be considered as simply or even primarily an aural phenomenon.

If Hainge begins by acknowledging the polysemy of the term noise and the heterogeneity of its uses, he also wants to delineate a consistency in noise's mutable apparitions: 'In essence, then, for it is indeed a question of essence, noise will be seen to constitute the nature or essence of the relation that is inimical to all expression when everything is conceived of as an expression.' (14) Thus, Hainge 'believes' in an ontology of noise invested 'only' in 'difference, becomings and relations' in which noise functions as the privileged name for the impossibility of totalisation under all and any conditions. Noise does not simply designate an epistemological or control limit for Hainge but comprises a relative force of irreparable unbinding. Across eight chapters, Hainge runs through an irregular but illuminating sequence of cultural situations and texts in which noise proves determining, including the early Futurist experiments of Luigi Russolo, Jean-Paul Sartre's Nausea, horror cinema, fuzzy typography, glitch music, musique concrète, the films of David Lynch, Thomas Ruff's photography and the work of Japanese noise artist, Merzbow.

Most appealing about Hainge's method is his acknowledgment of these contributions to the emergence of noise as a crucial determinant in cultural practices of all kinds. Yet he also pinpoints artistic omissions or retreats from the 
radical implications of noise. Hence Russolo's invention of intonarumori or noisemakers is shown to introduce a post-industrial Futurism into the regime of sound yet remain 'bounded by the will to dominate that was so prevalent in the extremely masculinist, virile, proto-Fascist Futurist mentality'. (49) Ditto for the anti-Fascist Jean-Paul Sartre, whose great philosophical novel, Nausea is rent by the same aporia whereby, 'as much as Roquentin may then claim to have become his nausea, ultimately he does not attend to it, or mishears it, as he does with noise throughout the novel'. (79) Hainge's book is packed with detail about such things as the etymological relation between nausea and noise:

noise has its roots in the Old French 'noise', meaning uproar or brawl and found in modern-day French only in the phrase 'chercher noise'-to pick a quarrel. 'Noise' itself can be traced back to the Latin nausea which evokes disgust, annoyance or discomfort. (67)

Other chapters demonstrate analogous features of noise in a diverse range of texts: popular Hollywood cinema, art-photography, experimental noise music, and so on.

As this wide inventory suggests, the discovery of the diverse powers of noise was one of the great aesthetic-and anti-aesthetic-programs of the twentieth century. In every domain, from avant-garde experimentalism through new media innovation to mathematical formalisation, noise functions as at once a privileged material, a radical theme and a disjunctive operation. Examples could be drawn from an astonishing range of practices that go well beyond Hainge's own focus, such as contemporaneous developments in the natural sciences. When thermodynamics is supplanted by cybernetics - that is, when energy gives way to information-noise becomes both the background against which a signal can emerge and the ineradicable risk of signal itself, its product and interruption. Simultaneously background, effect and rupture, the attempt to control noise creates more noise.

Thanks to the genius of the mathematician and information theorist Claude Shannon, we can generate an algebraic equation to represent this conundrum silently as the 'average logarithm of the improbability of [a] message; in effect, a measure of unexpectedness: $H=-\Sigma \mathrm{p}_{\mathrm{i}} \log _{2} \mathrm{p}_{\mathrm{i}}$ Where $\mathrm{p}_{\mathrm{i}}$ is the probability of each message'. ${ }^{2}$ What, then, is $H$ ? As the media and technology historian James Gleick explains in his recent book on information: ' $H$ is ubiquitous, conventionally called the entropy of a message, or the Shannon entropy, or, simply, the information.' (229) 
Shannon's formula concerns the probability of message error, a kind of ur- or metamessage principle that takes noise into account from the first.

But mathematico-logico-technical interventions are not of interest to Hainge, being too formal and technical for his purposes. Similarly, because of his resolutely modernist and cultural focus Hainge isn't that interested in the history of political struggles over the control of noise. Yet Plato's Republic, to give a foundational instance, sets out in post-Pythagorean fashion to purify the sound of noise, to ensure the stability and consistency of communication, and to regulate the earthly extraction of the idea from becoming. That is, the noise of ordinary existence will be transmuted by the proper political architecture into as noise-free a zone as possible. As such, the question regarding the deleterious effects of noise on health becomes paramount, even paradigmatic. As Evanghelos Moutsopoulos asserts in 'Psycho- and Bio-Cybernetics in Plato's Acoustics and Theory of Education,' Plato wishes to establish 'a method of habit through which either anticipated immunity from disease or cure of states of psychic abnormality is obtained.'3 Plato's attentiveness to prudential biomusicological architecture is echoed today by WHO pop-health studies that declare: 'Excessive noise seriously harms human health ... It can disturb sleep, cause cardiovascular and psychophysiological effects, reduce performance and provoke annoyance responses and changes in social behaviour.' ${ }^{4}$ It is not that Hainge is unaware of this philosophical history; indeed, it is the presupposed but unthematised backdrop against which his cultural ontology stands out and from which takes its distance. This is as much a question of disciplinary affiliation as it is of theme: to be blunt, this is cultural studies distinguishing itself from philosophy's history of noise-exclusion and its radically differing ideals of the relation of noise to health or the care for the self.

As the philosopher Ray Brassier comments in an interview about the intimate relations of philosophy, science and noise, 'the point is not just that science enriches and amplifies our understanding of reality, but that it uncovers the truth. Noise has no such epistemic valence. ${ }^{5}$ Here we find-à la Hainge and other noise theoriststhat the short-circuiting of truth and sense recurs in the invocation of the bond between noise and affect. Yet, unlike Hainge, Brassier argues that the disruptions effected by noise are not only not ontological effects, but are barely epistemological events. When Brassier examines noise, it is not to produce an ontology but to 
account for the precise power of noise to destroy genres on which ontology and aesthetics rely. ${ }^{6}$ Yet it is precisely the anti-aesthetic quality of noise which Hainge 'believes' able to found an ontology.

Hainge is certainly aware of the difficulties of ontological thinking around noise. Governing his methodology is the metaphor of a dog chasing its own tail, sketching out in the evanescent cycles of its own desperate endeavours the lineaments of what it can never quite catch-except at its own cost. But this image in itself can neither explain nor justify the question: Why an ontology of noise at all? Why not an epistemology? Or a thematic? Or a cultural practice? What gives the ontology of noise critical pertinence? What's wrong with calling a book Some Recent Moments in Noise or A Cultural History of Twentieth-Century Noise? This is more than a matter of nomenclature. The popular return to ontology can be dated to 1988 , when Alain Badiou published his massive metaphysical treatise Being and Event, which re-establishes the pertinence and necessity of ontological concerns from within the prevailing anti-philosophy of the continental tradition. ${ }^{7}$ In Badiou's aftermath, there has been a return to ontology in all sorts of domains that were once not only foreign to such talk but explicitly hostile. I've lost count of the number of anthropology, art history and legal conferences I've attended in the last few years that brandish 'ontology' in their titles and calls for papers. Think, too, of the proliferation of field monikers-ooo, speculative realism, thing theory-that push getting back to 'speaking of the real'. Though this return to ontology finds its license in Badiou's bulky treatise, it often operates without awareness of its contents and claims.

The new ontologists, it should be said, are not interested in philosophy. Certainly, Hainge's book is not a work of philosophy. Nor is it a work of psychoanalysis, which is almost totally absent from this book aside from reference to the work of Julia Kristeva. This is a problem for at least two reasons. First, noise is the inassimilable-yet-recurring-indifference residue of a subject. As such, it is essentially anti-ontological. Second, psychoanalysis has been a real influence, even if in the form of the negative example, upon many of the cultural phenomena studied here. Hence, the question of the fraught transmission of unspeakable messages or associative noise in the analysand's speech ought also to be part of the discussion. 
However, the analytic example of noise begetting noise might compromise the putative ontology of Hainge's project.

Even if we accept the terms upon which Hainge relies, we could perhaps find other themes that serve much the same function as noise: silence, for example. As Deleuze puts it:

Information theory implies a maximum of theoretical information; then at the opposite pole it puts pure noise, interference; and between the two, redundancy, which detracts from information but puts it on a higher level than noise. It's the other way round: at the top you should put redundancy as the transmission and repetition of orders and commands; below that information, always a minimum requirement if commands are to be understood. And below that? Well, there would be something like silence, or stammering, or a cry, something which would flow under redundancy and information, which would make language flow and still make itself understood. $^{8}$

Whatever you think about this passage from Deleuze, it is not offering an ontology of noise but seeks to characterise the absolute as something that would 'be like ... or ... or.' Although Hainge's book is neither philosophy nor psychoanalysis it remains indebted to both. Is this the status of cultural studies, a kind of metaphysics-withoutphilosophy? This is not simply an intra-institutional remark but a reflection on the global situation, methods and themes of contemporary research. While philosophy and psychoanalysis are not solely university-derived disciplines, cultural studies was, is and must remain the product of the university even as the university mutates into a kind of corporate beast relentlessly reasserting its control over noise. Hainge's study responds to the institutional unmooring of cultural studies with recourse to 'ontology'. What makes his book a more interesting study than many of the other 'ontologies' currently on offer is that, rather than promulgating a return to (lowgrade phantasy) objects, Hainge focuses on the anti-object par excellence, the nothing that is noise. Now that's a noise we can all feel, if not in the way Slade intended. 
Justin Clemens is a senior lecturer in Culture and Communication at the University of Melbourne. Recent books include Psychoanalysis is an Antiphilosophy (2013) and, with A.J. Bartlett and Jon Roffe, Lacan Deleuze Badiou (2014). His mock epic poem The Mundiad (2013) was shortlisted for the 2014 Kenneth Slessor Prize.

\footnotetext{
-NOTES

1 Jonathan Sterne's massive anthology, The Sound Studies Reader, Routledge, New York, 2012, is evidence of the success of this emergent sub-discipline. However, in line with the work of Hainge and others, noise studies turns out to be a different beast. In this regard, see, 'On Noise', a special section of Cultural Studies Review, vol. 18, no. 3, 2012, co-edited by Bruce Buchan and David Ellison, which makes a significant contribution to the current theoretical hubbub in this area.

2 James Gleick, The Information: A History, a Theory, a Flood, Fourth Estate, London, 2011, p. 228.

3 Evanghelos Moutsopoulos, 'Psycho- and Bio-Cybernetics in Plato's Acoustics and Theory of Education', Sobretiro de Humanitas, no.19, Universidad de Nuevo León, 1978, p. 58.

${ }^{4}$ WHO, 'Noise,' <http://www.euro.who.int/en/health-topics/environment-and-health/noise/noise>; accessed 26 May 2014.

${ }^{5}$ Ray Brassier and Bram Ieven, 'Transitzone/Against an Aesthetics of Noise', $N Y, 5$ October 2009,

<http://www.ny-web.be/transitzone/against-aesthetics-noise.html>; accessed 26 May 2014.

${ }^{6}$ See Ray Brassier, 'Genre is Obsolete,' in Mattin and Anthony Iles (eds), Noise and Capitalism, Arteleku Audiolab, Donostia-S.Sebasitia, 2009, pp. 61-71.

7 See Alain Badiou, Being and Event, trans. Oliver Feltham, Continuum, London, 2005.

8 Gilles Deleuze, 'On Sur et Sous La Communication: Three Questions on Six Fois Deux', in David Wilson (ed.), Cahiers du Cinéma: Volume Four, 1973-1978, Routledge, London, 2000, p. 127.
}

\section{-BIBLIOGRAPHY}

Badiou, A., Being and Event, trans. Oliver Feltham, Continuum, London, 2005.

Brassier, R. and B. Ieven, 'Transitzone/Against an Aesthetics of Noise', NY, 5 October 2009, <http://www.ny-web.be/transitzone/against-aesthetics-noise.html>.

Brassier, R., 'Genre is Obsolete', in Mattin and Anthony Iles (eds), Noise and Capitalism, Arteleku Audiolab, Donostia-S.Sebasitia, 2009.

Cultural Studies Review, vol. 18, no. 3, 2012, 'On Noise' special section, co-edited by Bruce Buchan and David Ellison.

Deleuze, G., 'On Sur et Sous La Communication: Three Questions on Six Fois Deux', in David Wilson (ed.), Cahiers du Cinéma: Volume Four, 1973-1978, Routledge, London, 2000. 
Gleick, J., The Information: A History, a Theory, a Flood, Fourth Estate, London, 2011.

Iles, M. and A. (eds), Noise and Capitalism, Arteleku Audiolab, Donostia-S.Sebasitia, 2009.

Moutsopoulos, E., 'Psycho- and Bio-Cybernetics in Plato's Acoustics and Theory of Education', Sobretiro de Humanitas, no.19, Universidad de Nuevo León, 1978.

Sterne, J., The Sound Studies Reader, Routledge, New York, 2012.

WHO, 'Noise,' <http://www.euro.who.int/en/health-topics/environment-and-health/noise/noise>.

Wilson, D., (ed.), Cahiers du Cinéma: Volume Four, 1973-1978, Routledge, London, 2000. 